\title{
Seasonal distribution of airborne pollen in Ulsan, Korea in 2009-2010
}

\author{
Seung-Hyeok Choi ${ }^{1}$, In-Yong Jung ${ }^{1}$, Dong-Yeop Kim ${ }^{1}$, Yang-ho Kim² ${ }^{2}$ Ji-Ho Lee $^{2}$, In-Bo Oh ${ }^{3}$ and \\ Kee-Ryong Choi ${ }^{1, *}$ \\ ${ }^{1}$ Department of Biological Sciences, University of Ulsan, Ulsan 680-749, Korea \\ ${ }^{2}$ Department of Occupational and Environmental Medicine, Ulsan University Hospital, University of Ulsan College of Medicine, \\ Ulsan 682-714, Korea \\ ${ }^{3}$ Environmental Health Center, University of Ulsan, Ulsan 682-714, Korea
}

\begin{abstract}
To determine the peak dispersal times of allergenic pollen grains in Ulsan, Korea, we performed continuous airborne pollen counts at three stations (Sts. A, B, and C) in Ulsan from August 2009 to November 2010. Pollen grains were sampled using a Durham sampler. Two peak pollen dispersal seasons were observed per year. The peak seasons generally coincided with the flowering period of anemophilous trees: Taxodiaceae (February), Alnus (March), Cupressaceae (April), Quercus, and Pinus (May), and with the flowering phase of herbs from August to November, e.g., Humulus, Artemisia, Gramineae, and Ambrosia from August through September. The highest concentration of airborne pollen was from Pinus (68\%), followed by Quercus (15\%), Alnus (6\%), and Humulus (2\%); whereas very low pollen concentrations were from Taxodiaceae, Cupressaceae, Artemisia, Gramineae, and Ambrosia ( $\leq 1 \%$ of the annual total airborne pollen concentration). Our findings indicate that Alnus and Humulus pollen are major allergens whereas those of Pinus and Quercus are minor allergens. The concentration of Alnus pollen grains at St. C was over five times that at Sts. A and B. This finding implies that individuals living at or near St. C are exposed to high concentrations of Alnus pollen before and after March, which is the flowering period of the alder tree. From August to September, individuals living at or near St. B are exposed to high concentrations of Humulus pollen. Our study suggests that Alnus pollen may be the major aeroallergen causing pollinosis in the spring at St. C and Humulus pollen may be the major aeroallergen in autumn at St. B.
\end{abstract}

Key words: airborne pollen, allergenic pollen, pollen calendar, pollinosis, Ulsan

\section{INTRODUCTION}

Particles dispersed in the air are referred to as aerosols. While it is difficult to detect bacteria and viruses in aerosols, it is relatively easy to detect algae, leaf hairs, seeds, plant fragments, and pollen (Knox 1979). Aerosols are under the control of atmospheric conditions, and are normally carried across short distances; however, ascending air currents can carry aerosols much farther (Nilsson
1973). Pollen is a type of aerosol that may induce an allergic response (i.e., pollinosis) in susceptible humans (D'Amato et al. 2007). One representative characteristic of pollinosis is seasonality of symptoms, which means that this disease occurs at the same time every year (D'Amato et al. 1998). Furthermore, symptoms are aggravated in a manner directly proportional to an increase in airborne

\section{Open Access http://dx.doi.org/10.5141/JEFB.2011.039}

This is an Open Access article distributed under the terms of the Creative Commons Attribution Non-Commercial License (http://creativecommons. org/licenses/by-nc/3.0/) which permits unrestricted non-commercial use distribution, and reproduction in any medium, provided the original work is properly cited.
Received 24 August 2011, Accepted 05 September 2011

*Corresponding Author

E-mail:pollen@ulsan.ac.kr Tel: $+82-52-259-2397$ 
pollen concentration (Oh et al. 2006, Agashe and Caulton 2009).

The study of pollinosis in Korea started with Joo (1965), and has since been carried out in Seoul and the Gyeonggi region (Min and Kang 1984, Hong et al. 1986, Chang et al. 1988, Oh 1998). Since 1996, the Pollen Research Center of the Korean Academy of Pediatric Allergy and Respiratory Disease (KAPARD) has been performing pollinosis studies in eight major Korean cities (Busan, Daegu, Daejeon, Gangneung, Guri, Gwangju, Jeju, Seoul). Although Ulsan, a city of industrial complexes, is a more sensitive region for environmental diseases than other cities, quantitative studies of such diseases in this region have been lacking. Ulsan is not included in the eight cities in which KAPARD is performing pollinosis studies. In fact, there have been no studies of pollinosis, a suspected environmental disease in Ulsan. Since symptoms of pollinosis can differ according to climate, plant distribution, and vegetation, local differences must exist (Falagiani 1990, D'Amato et al. 1998). Therefore, locally specific studies on airborne pollen have immense value for the prevention and cure of environmental diseases (Ong et al. 1995). In this study, we investigated the spatial-temporal distribution characteristics of airborne pollen by conducting a pollen survey in Ulsan from August 2009 to November 2010. We also developed a pollen calendar on the basis of the survey results.

\section{MATERIALS AND METHODS}

\section{Study area}

Ulsan is in the southeastern part of the Korean Peninsula adjoining the East Sea. Major drainage systems of this region are the Taehwa River, the Woehwang River, and the Heoya River. The heavy chemical industries - Ulsan Petrochemical Complex and Onsan National Industrial Complex - lie along the southeastern coast of Ulsan. Climatic information for the region was obtained from meteorological data collected over 30 years from 1980 to 2009 by the Ulsan meteorological administration (Korea Meteorological Administration 2010). The annual mean temperature was $14.1^{\circ} \mathrm{C}$, and the annual mean precipitation was $1,304.4 \mathrm{~mm}$. Annual precipitation measured from June to September was $64.5 \%$, with minimum precipitation recorded in December $(22.5 \mathrm{~mm})$ and January $(34.7 \mathrm{~mm})$. The lowest recorded temperature was $-11.9^{\circ} \mathrm{C}$ (on January 18, 1980), and the highest recorded temperature was $38.6^{\circ} \mathrm{C}$ (on August 3,1983 ). For 231 days, the daily mean temperature was over $10^{\circ} \mathrm{C}$. In December, January, and February, the daily minimum temperature was below $0^{\circ} \mathrm{C}$. All data gathered indicate that Ulsan has four seasons and belongs to the temperate zone with heavy rain typical in the summer.

Three sampling stations (Sts.) were chosen on the basis

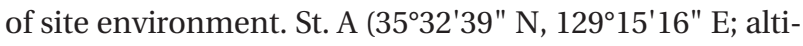
tude, $74 \mathrm{~m}$ ) was close to Mt. Munsu, which is on the outskirts of the city and considered a source of pollen from the mountain. St. B $\left(35^{\circ} 33^{\prime} 11^{\prime \prime} \mathrm{N}, 129^{\circ} 21^{\prime} 22^{\prime \prime} \mathrm{E}\right.$; altitude, 43 $\mathrm{m})$ was chosen to study residential districts and riparian plant communities and St. C (35²9'50" N, 129 $25^{\circ} 16^{\prime \prime}$ E; altitude, $66 \mathrm{~m}$ ) was selected to reflect coastal vegetation and residential districts (Fig. 1).

\section{Sampling of airborne pollen}

Durham samplers were used to trap airborne pollen grains (Ogden et al. 1974). Two horizontal $23 \mathrm{~cm}$ circular disks were set $7.6 \mathrm{~cm}$ apart from each other. A mount for positioning a glass slide was placed between the disks, $2.5 \mathrm{~cm}$ away from the bottom disk and $1.5 \mathrm{~m}$ above the ground. Samplers were installed on roofs with no air-handling units to ensure they were set in open spaces convenient for changing the glass slides. The pollen samplers were not moved during the research period from August 1, 2009 to November 30, 2010.

Vaseline was applied to the surface of the glass slides $(76 \times 26 \mathrm{~mm}$ ), which were then installed for $24 \mathrm{~h}$ on the sampler. Glass slides were changed every day at 9 a.m. If glass slides were wet, precipitation was allowed to dry naturally. For preservation, glass slides were stained and sealed using the gentian violet glycerin jelly method and an $18 \times 18 \mathrm{~mm}$ cover glass.

\section{Pollen counts}

Airborne pollen was measured using standardized procedures for atmospheric pollen counts and pollen forecasts employed by the Japan Allergy Foundation (Sahashi et al. 1993). The pollen grain count was rounded up from two to one decimal point. The start date of observation was defined as the day, starting from January 1 , when the pollen count was rounded up to one decimal point. The beginning of pollen scattering was defined as the first day on which pollen was detected for more than two consecutive days, with a first day value of one grain $/ \mathrm{cm}^{2}$. The ending date of the main pollen season was defined as the day prior to the first three consecutive days of zero grain detection. 


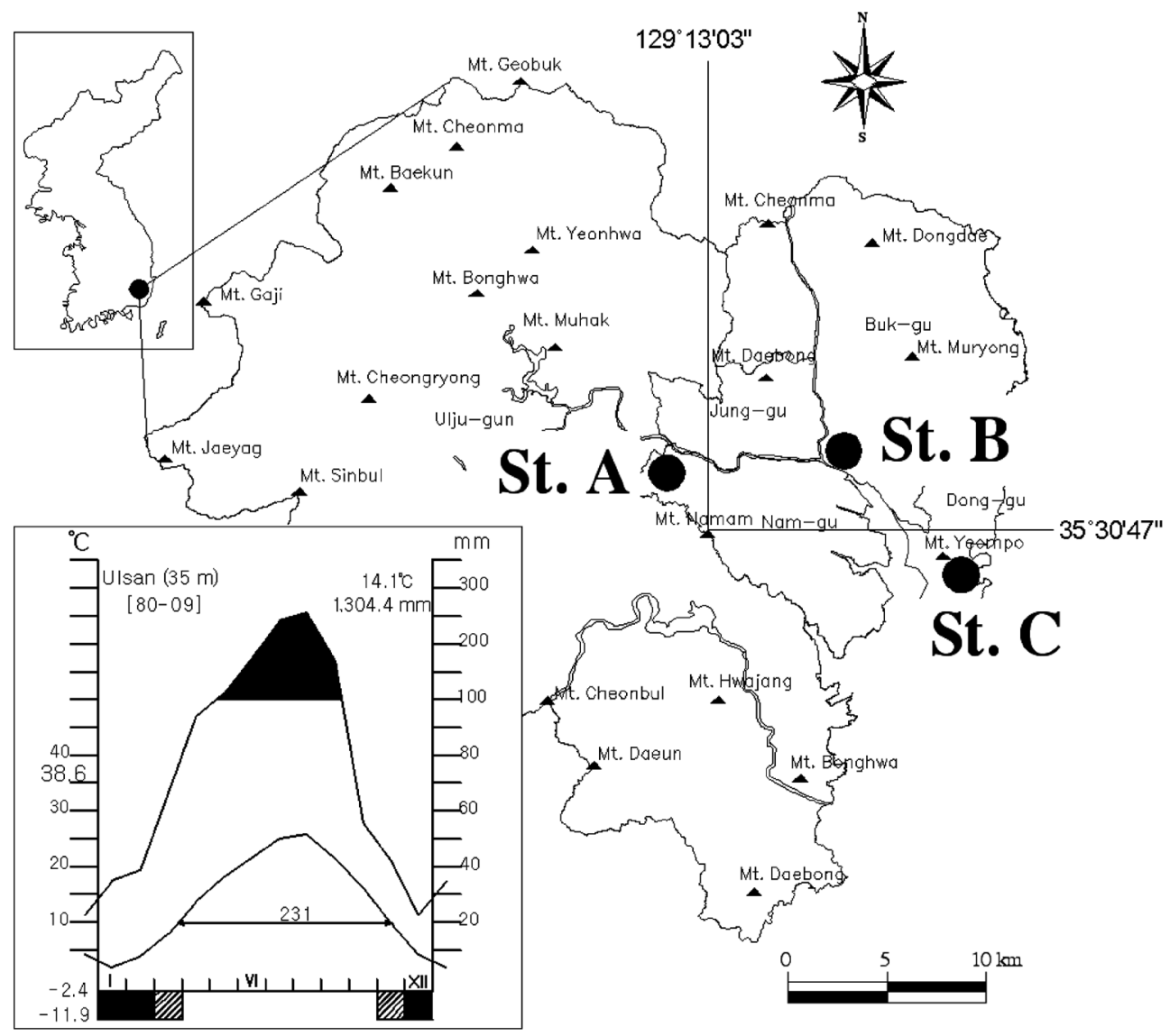

Fig. 1. Map and location of three sampling stations for collection of airborne pollen and climate diagram of Ulsan. St. A, Station near the outskirt of the city; St. B, New residential area and surrounding river floodplain; St. C, Coastal residential area.

\section{RESULTS}

\section{Distribution of airborne pollen}

The total pollen counted during the study period from August 1, 2009 to July 31, 2010 was 16,762.3 grains $/ \mathrm{cm}^{2}$ at St. A, 13,353.4 grains $/ \mathrm{cm}^{2}$ at St. B, and $17,495.7$ grains $/ \mathrm{cm}^{2}$ at St. C. St. A accounted for $35 \%$ of the total pollen grain measured in Ulsan in one year, whereas St. B and St. C accounted for $28 \%$ and $37 \%$ of total pollen, respectively. Tree pollen (TP) was detected the most at St. C (37\%), and herb pollen (HP) was detected the most at St. B (49\%) (Fig. 2).

We identified 44 families and 46 genera of pollen in Ulsan. The TP types identified at Sts. A (25 families, 30 genera) and C (24 families, 30 genera) were more than those identified at St. B (21 families, 28 genera). The types of HP detected at St. B (15 families, 12 genera) were more than those detected at St. C (14 families, 10 genera) and St. A (12 families, 9 genera). The proportion of total pollen that was TP was $96.9 \%$ at St. A, $92.3 \%$ at St. B, and $96.7 \%$ at St.

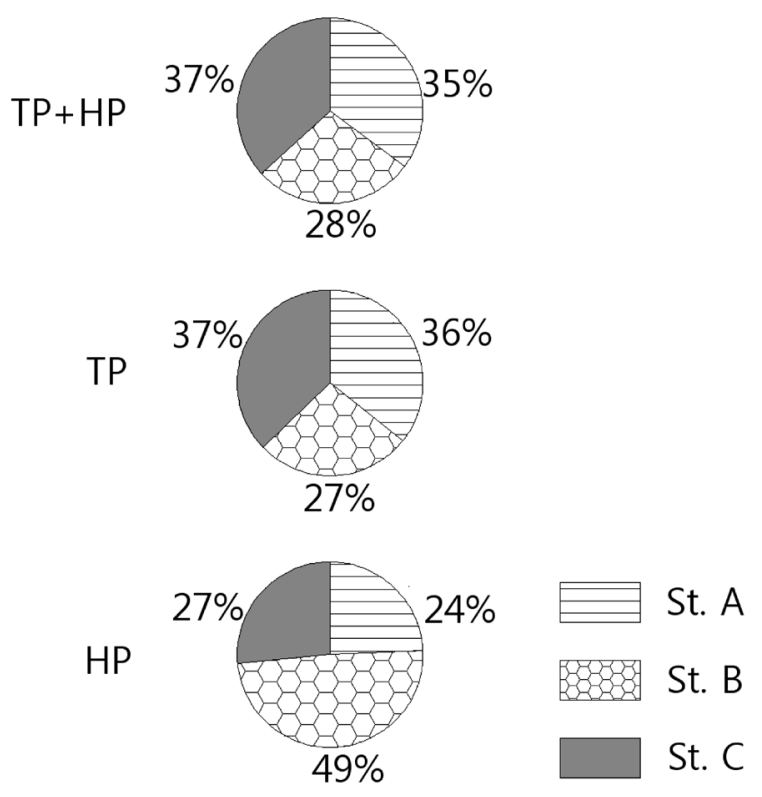

Fig. 2. Comparison of percentage of tree pollen (TP) and herb pollen (HP) at three stations in Ulsan (Aug 1, 2009-Jul 31, 2010). 


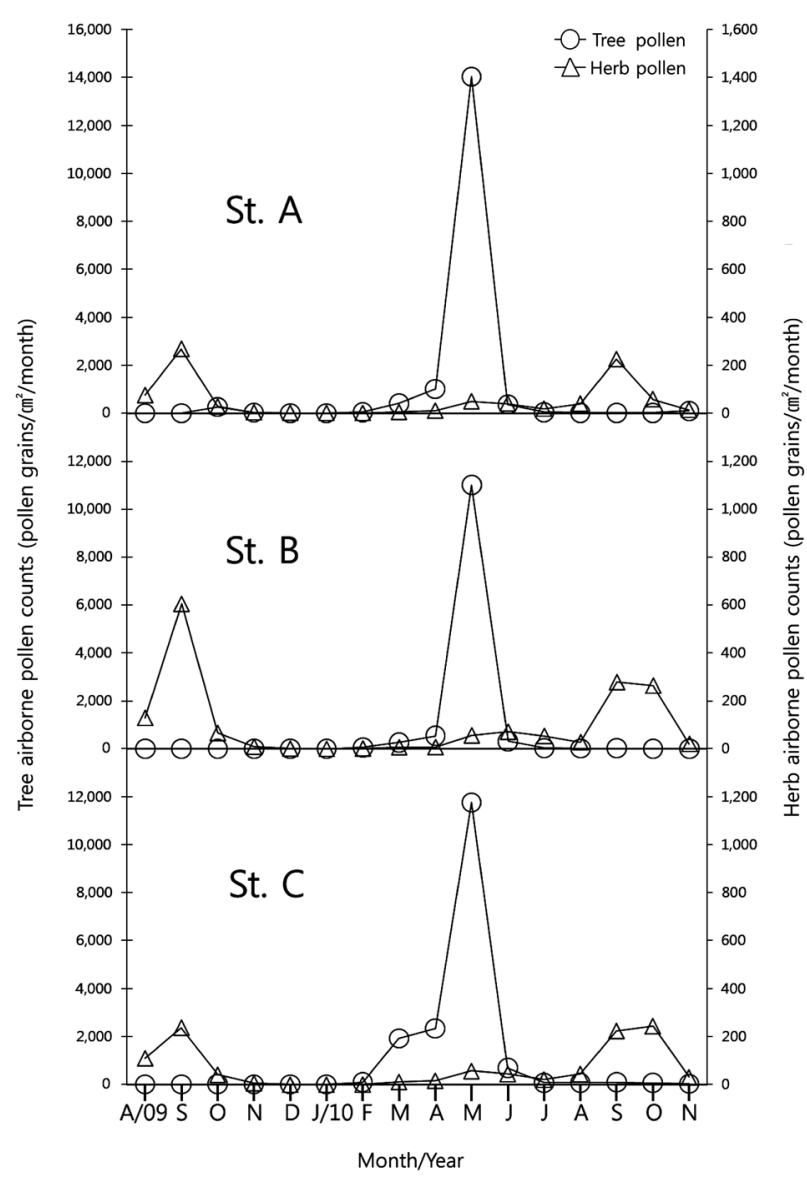

Fig. 3. Concentrations of pollen grains $/ \mathrm{cm}^{2} /$ month of tree and herb plants (Aug 1, 2009-Jul 31, 2010).
C. The dominant airborne pollens at St. A, in order from highest to lowest concentration, were Pinus $(11,435.8$ grains $\left./ \mathrm{cm}^{2}, 68.2 \%\right)$, Quercus (3,132.4 grains $/ \mathrm{cm}^{2}, 18.7 \%$ ), Alnus (384.9 grains $/ \mathrm{cm}^{2}, 2.3 \%$ ), Cedrus (291.4 grains $/ \mathrm{cm}^{2}$, $1.7 \%)$, Humulus (241.7 grains $/ \mathrm{cm}^{2}, 1.4 \%$ ), and Cupressaceae $\left(232.4\right.$ grains $\left./ \mathrm{cm}^{2}, 1.4 \%\right)$. At St. B, the corresponding order was Pinus $\left(9,472.5\right.$ grains $\left./ \mathrm{cm}^{2}, 71 \%\right)$, Quercus (1,900.9 grains $\left./ \mathrm{cm}^{2}, 14.2 \%\right)$, Humulus (505.3 grains $/ \mathrm{cm}^{2}$, 3.8\%), Alnus (323.8 grains $\left./ \mathrm{cm}^{2}, 2.4 \%\right)$, Gramineae (170.4 grains $/ \mathrm{cm}^{2}, 1.3 \%$ ), and Artemisia (156.5 grains $/ \mathrm{cm}^{2}$, $1.2 \%)$; whereas that at St. C was Pinus (11,606.5 grains/ $\left.\mathrm{cm}^{2}, 66.3 \%\right)$, Quercus (2,278.7 grains $\left./ \mathrm{cm}^{2}, 13 \%\right)$, Alnus (2,194.8 grains $\left./ \mathrm{cm}^{2}, 12.5 \%\right)$ and Humulus (252.8 grains/ $\left.\mathrm{cm}^{2}, 1.4 \%\right)$. The detected concentration of Alnus pollen at St. C was five times higher than that at Sts. A and B. The concentration of Humulus pollen at St. B was twice that at Sts. A and C (Table 1).

Monthly variations in airborne pollen concentrations at the three stations from August 2009 to November 2010 are shown in Fig. 3. At all stations, three pollen peak seasons occurred at the same times. The first peak season occurred between August and November of 2009 and was attributable to HP. The second and the highest peak season occurred between February and June and was attributable to TP. The third peak season occurred between August and November of 2010 and was attributable to HP. The detected pollen concentration at St. C in March was higher than at Sts. A and B and was attributable to Alnus pollen.

\section{Pollen calendar}

Data regarding the types of airborne pollen at each of the three stations was combined. The 34 most dominant types of pollens are presented in a pollen calendar. High and low concentrations of the 34 dominant pollens are presented in Figs. 4 and 5, respectively.

\section{Tree pollen}

In the TP peak season, pollens of Alnus, Taxodiaceae, Cupressaceae, Quercus, and Pinus were detected at high levels (95\%).

For Alnus pollen, the first day of observation was January 15, scattering began on February 22, the season ended on May 8, and the peak value was recorded on March 13 (134.9 grains $\left./ \mathrm{cm}^{2}\right)$.

For Taxodiaceae pollen, the first day of observation was February 17, scattering began on February 24, the season ended on April 19, and the peak value was noted on Feb-
Fig. 4. Airborne pollen calendar of the principal tree and herb pollen types of Ulsan depicting unified data obtained from three sampling stations (Aug 1, 2009-Nov 30, 2010). 
Table 1. Annual counts of airborne pollen types at three sampling stations (Aug 1, 2009-Jul 31, 2010)

\begin{tabular}{|c|c|c|c|c|c|c|}
\hline & \multirow{2}{*}{ Family } & \multirow{2}{*}{ Genus } & \multicolumn{4}{|c|}{ Pollen grains $/ \mathrm{cm}^{2}$} \\
\hline & & & St. A & St. B & St. C & Ulsan \\
\hline \multirow[t]{48}{*}{ Tree pollen } & Pinaceae & & $11,747.8$ & $9,494.5$ & $11,628.7$ & $32,871.0$ \\
\hline & & Pinus spp. & $(11,435.8)$ & $(9,472.5)$ & $(11,606.5)$ & $(32,514.8)$ \\
\hline & & Cedrus spp. & (291.4) & $(5.3)$ & $(14.8)$ & (311.4) \\
\hline & & Larix spp. & $(20.7)$ & $(16.7)$ & $(7.4)$ & $(44.8)$ \\
\hline & Fagaceae & & $3,313.6$ & $2,028.4$ & $2,353.7$ & $7,695.7$ \\
\hline & & Quercus spp. & $(3,132.4)$ & $(1,900.9)$ & $(2,278.7)$ & $(7,312.0)$ \\
\hline & & Castanea spp. & (164.5) & (110.5) & $(43.8)$ & (318.8) \\
\hline & & Cyclobalanopsis spp. & $(16.7)$ & $(17.0)$ & $(31.2)$ & $(64.8)$ \\
\hline & Betulaceae & & 467.9 & 392.6 & $2,295.4$ & $3,155.9$ \\
\hline & & Alnus spp. & $(384.9)$ & (323.8) & $(2,194.8)$ & $(2,903.4)$ \\
\hline & & Betula spp. & (39.8) & $(41.4)$ & $(63.0)$ & (144.1) \\
\hline & & Carpinus spp. & $(29.0)$ & (18.5) & $(17.6)$ & $(65.1)$ \\
\hline & & Corylus spp. & $(14.2)$ & $(9.0)$ & $(20.1)$ & $(43.2)$ \\
\hline & Cupressaceae & & 232.4 & 102.2 & 159.6 & 494.1 \\
\hline & Taxodiaceae & & 134.9 & 69.1 & 117.0 & 321.0 \\
\hline & Ulmaceae & & 102.2 & 69.1 & 107.4 & 278.7 \\
\hline & & Ulmus spp. + Zelkova spp. & (71.3) & $(36.7)$ & $(46.3)$ & (154.3) \\
\hline & & Celtis spp. & $(30.9)$ & $(32.4)$ & $(61.1)$ & (124.4) \\
\hline & Ginkgoaceae & Ginkgo spp. & 83.0 & 55.9 & 45.4 & 184.3 \\
\hline & Juglandaceae & & 48.5 & 21.9 & 66.4 & 136.7 \\
\hline & & Platycarya spp. & $(45.1)$ & $(16.7)$ & $(56.2)$ & (117.9) \\
\hline & & Juglans spp. & $(2.2)$ & $(2.5)$ & $(8.6)$ & $(13.3)$ \\
\hline & & Pterocarya spp. & $(1.2)$ & $(2.8)$ & $(1.5)$ & (5.6) \\
\hline & Moraceae & Morus spp. & 40.1 & 29.9 & 56.2 & 126.2 \\
\hline & Rosaceae & & 20.0 & 14.2 & 23.8 & 58.0 \\
\hline & Salicaceae & & 6.2 & 18.5 & 23.5 & 48.2 \\
\hline & & Salix spp. & (3.1) & (14.5) & $(15.4)$ & $(33.0)$ \\
\hline & & Populus spp. & $(3.1)$ & $(4.0)$ & $(8.0)$ & $(15.1)$ \\
\hline & Oleaceae & & 12.0 & 6.5 & 8.9 & 27.4 \\
\hline & Leguminosae & & 0.6 & - & 0.3 & 0.9 \\
\hline & Taxaceae & & 5.9 & 4.9 & 1.2 & 12.0 \\
\hline & Plantanaceae & Platanus spp. & 6.5 & 5.9 & 2.5 & 14.8 \\
\hline & Anacardiaceae & Rhus spp. & 3.7 & 2.8 & 3.4 & 9.9 \\
\hline & Aceraceae & Acer spp. & 1.2 & 0.6 & 5.6 & 7.4 \\
\hline & Buxaceae & Buxus spp. & 1.2 & 1.9 & 2.8 & 5.9 \\
\hline & Hippocastanaceae & Aesculus spp. & 2.5 & 0.3 & 0.3 & 3.1 \\
\hline & Ericaceae & & 0.6 & - & - & 0.6 \\
\hline & Caprifoliaceae & Viburnum spp. & 0.9 & - & 1.5 & 2.5 \\
\hline & Palmae & Trachycarpus spp. & - & 0.3 & 0.6 & 0.9 \\
\hline & Tiliaceae & Tilia spp. & - & 0.3 & 0.6 & 0.9 \\
\hline & Myricaceae & Myrica spp. & 0.6 & - & - & 0.6 \\
\hline & Theaceae & Camellia spp. & 0.3 & - & 0.3 & 0.6 \\
\hline & Lythraceae & Legerstroemia spp. & 0.6 & - & - & 0.6 \\
\hline & Ranunculaceae & Clematis spp. & - & 0.3 & - & 0.3 \\
\hline & Aquifoliaceae & Ilex spp. & - & - & 0.3 & 0.3 \\
\hline & Rhamnaceae & Zizyphus spp. & 0.3 & - & - & 0.3 \\
\hline & Total tree pollen & & $16,250.6$ & $12,326.5$ & $16,918.2$ & $45,495.3$ \\
\hline & Percentage & & $96.9 \%$ & $92.3 \%$ & $96.7 \%$ & $95.6 \%$ \\
\hline
\end{tabular}


Table 1. Contiuned

\begin{tabular}{|c|c|c|c|c|c|c|}
\hline & \multirow{2}{*}{ Family } & \multirow{2}{*}{ Genus } & \multicolumn{4}{|c|}{ Pollen grains $/ \mathrm{cm}^{2}$} \\
\hline & & & St. A & St. B & St. C & Ulsan \\
\hline \multirow[t]{23}{*}{ Herb pollen } & Cannabinaceae & Humulus spp. & 241.7 & 505.3 & 252.8 & 999.7 \\
\hline & Compositae & & 91.4 & 232.4 & 105.9 & 429.6 \\
\hline & & Ambrosia spp. & $(19.1)$ & $(34.0)$ & $(13.0)$ & $(66.1)$ \\
\hline & & Artemisia spp. & $(62.0)$ & (156.5) & $(86.7)$ & $(305.3)$ \\
\hline & & Others & $(10.2)$ & $(42.0)$ & $(6.2)$ & $(58.3)$ \\
\hline & Gramineae & & 109.9 & 170.4 & 100.0 & 380.3 \\
\hline & Cyperaceae & & 12.7 & 38.3 & 12.0 & 63.0 \\
\hline & Chenopodiaceae & & 10.5 & 17.0 & 21.3 & 48.8 \\
\hline & Polygonaceae & & 14.8 & 15.7 & 15.4 & 46.0 \\
\hline & & Rumex spp. & (13.3) & (13.3) & $(14.2)$ & $(40.7)$ \\
\hline & & Polygonum spp. & (1.5) & $(1.5)$ & $(1.2)$ & $(4.3)$ \\
\hline & & Persicaria spp. & - & $(0.9)$ & - & $(0.9)$ \\
\hline & Aizoaceae & Dorotheanthus spp. & 2.2 & 4.6 & 16.1 & 22.8 \\
\hline & Cruciferae & & 3.7 & 5.3 & 9.0 & 17.9 \\
\hline & Euphorbiaceae & Acalypha spp. & 0.9 & 3.7 & 5.3 & 9.9 \\
\hline & Amaranthaceae & & 2.5 & 3.7 & 3.4 & 9.6 \\
\hline & Typhaceae & Typha spp. & - & 9.0 & 0.3 & 9.3 \\
\hline & Solanaceae & Solanum spp. & 7.1 & 0.9 & 0.9 & 9.0 \\
\hline & Plantaginaceae & Plantago spp. & 1.9 & 3.4 & 1.9 & 7.1 \\
\hline & Rubiaceae & Galium spp. & - & 1.5 & - & 1.5 \\
\hline & Labiatae & & - & 0.9 & 0.6 & 1.5 \\
\hline & Total herb pollen & & 499.7 & $1,012.0$ & 545.1 & $2,056.8$ \\
\hline & Percentage & & $3.0 \%$ & $7.6 \%$ & $3.1 \%$ & $4.3 \%$ \\
\hline \multirow[t]{3}{*}{ Unidentified } & & & 12.0 & 14.8 & 32.4 & 59.2 \\
\hline & Percentage & & $0.1 \%$ & $0.1 \%$ & $0.2 \%$ & $0.1 \%$ \\
\hline & Total (tree pollen + herb pollen) & & $16,762.3$ & $13,353.4$ & $17,495.7$ & $47,611.4$ \\
\hline \multicolumn{3}{|c|}{ Tree pollen + Herb pollen family $(F)$ and genus $(G)$} & 37F 39G & $36 \mathrm{~F} 40 \mathrm{G}$ & $38 \mathrm{~F} 40 \mathrm{G}$ & $44 \mathrm{~F} 46 \mathrm{G}$ \\
\hline
\end{tabular}

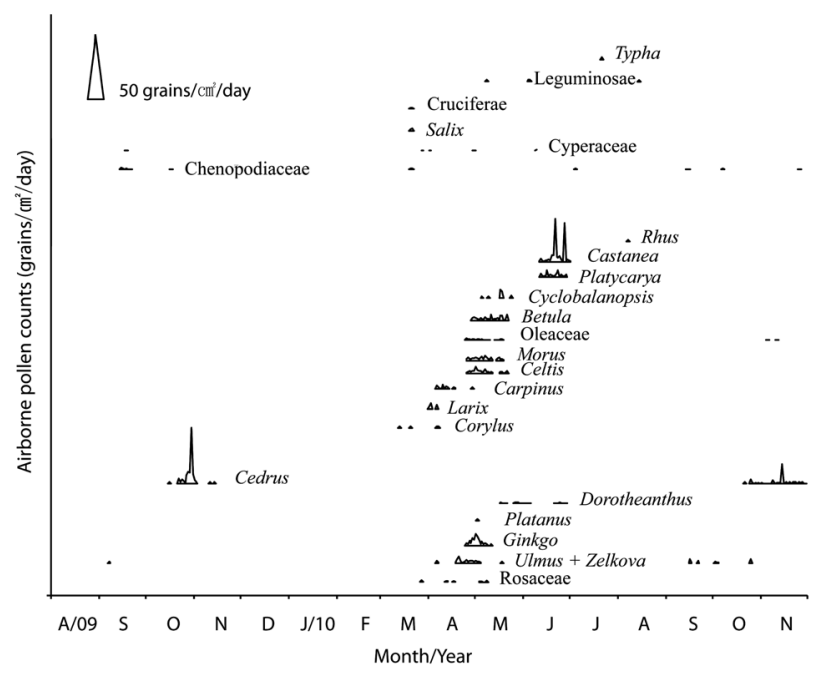

Fig. 5. Airborne pollen calendar of dominant tree and herb pollen grains with low concentrations in Ulsan (Aug 1, 2009-Nov 30, 2010) depicting unified data collected from three sampling stations. ruary 25 (31.9 grains $\left./ \mathrm{cm}^{2}\right)$.

For Cupressaceae pollen, the first day of observation was February 20, scattering began on March 12, the season ended on May 22, and the peak value was recorded on April 6 (15.5 grains $\left./ \mathrm{cm}^{2}\right)$.

For Quercus pollen, the first day of observation was March 21, scattering began on April 19, the season ended on July 11, and the peak value was recorded on May 5 (251.8 grains $\left./ \mathrm{cm}^{2}\right)$.

For Pinus pollen, the first day of observation was January 1, scattering began on April 22, the season ended on May 20, and the peak value was recorded on May 5 $\left(1,194.2\right.$ grains $\left./ \mathrm{cm}^{2}\right)$.

\section{Herb pollen}

During the peak season of HP from August to November, $95 \%$ of HP was attributable to Humulus (63\% in 2009, 
$65 \%$ in 2010), Artemisia (19\% in 2009, $15 \%$ in 2010), Gramineae (9\% in 2009, 12\% in 2010), and Ambrosia (4\% in 2009, $2 \%$ in 2010).

Artemisia, Humulus, and Gramineae pollen grains were recorded from August 1, 2009. For Artemisia pollen, in 2009, the beginning of pollen scattering was August 21, the season ended on October 9 , and the peak value was recorded on August 23 (8.5 grains $/ \mathrm{cm}^{2}$ ). In 2010, the first day of observation was July 3 , scattering began on September 16 , the season ended on November 1 , and the peak value was recorded on September 30 (8.3 grains $\left./ \mathrm{cm}^{2}\right)$.

For Humulus pollen, in 2009, scattering began on August 21 , the season ended on October 19, and the peak value was recorded on August 23 (28.9 grains $/ \mathrm{cm}^{2}$ ). In 2010, the first date of observation was July 4 , scattering began on August 31, the season ended on November 2, and the peak value was recorded on October 2 (13.4 grains $\left./ \mathrm{cm}^{2}\right)$.

For Ambrosia pollen, the first day of observation was August 14 in 2009 and August 3 in 2010. In 2009, Ambrosia pollen was continuously observed from August 18 to September 31, and in 2010, it was observed from September 1 to October 30; however, the level of Ambrosia pollen in both years was too low to measure pollen scattering. The peak value was detected on September 21 in 2009 (2.6 grains $\left./ \mathrm{cm}^{2}\right)$ and September 8 in $2010\left(0.8\right.$ grains $\left./ \mathrm{cm}^{2}\right)$.

Gramineae plants had two pollen seasons in a single year, May to June and August to September, whereas other plants had only a single pollen season per year. In 2009, pollen scattering occurred on August 22 and ended on November 2, and the peak value was recorded on September 12 (3.7 grains $/ \mathrm{cm}^{2}$ ). In 2010, pollen scattering began on May 17 and ended on June 28. Pollen scattering was recorded for a second time in 2010, from August 18 to November 11 . The peak values for each season were recorded on May 24 (3.5 grains $/ \mathrm{cm}^{2}$ ) and September 30 (3.4 grains $/ \mathrm{cm}^{2}$ ), respectively.

\section{Low concentration of TP and HP}

Low concentrations of TP and HP of dominant pollen were of the types listed below. Parent plants were identified on the basis of the local vegetation, and flowering season was determined on the basis of the detected pollens which were distributed into three groups based on the habitat of parent plants (Fig. 5). Group 1 included Typha, Leguminosae, Cruciferae, Salix, Cyperaceae, and Chenopodiaceae. The putative parent plants of these pollen grains were distributed in residential districts, at ruderal sites, and riversides. Group 2 included Rhus, Castanea, Platycarya, Oleaceae, Celtis, Morus, Carpinus, Larix, and Corylus. The putative parent plants of these pollen grains were native or growing plants at a fruit farm near the hillside. Group 3 included Cedrus, Dorotheanthus, Platanus, Ginkgo, Ulmus, Zelkova, Rosaceae, Betula and Cyclobalanopsis. The putative parent plants of these pollen grains were street trees and garden plants.

\section{DISCUSSION}

The pollen season in temperate climates is normally restricted to the flowering season from early spring to autumn (Knox 1979). Ulsan has a temperate climate with high temperature and humidity in the summer and is cold and dry in the winter. The annual airborne pollen concentration has two peak seasons (TP in spring and HP in autumn) (Fig. 3). The dominant pollen type per month was Taxodiaceae in February, Alnus in March, Cupressaceae in April, and Quercus, Pinus, and Gramineae in May. In autumn, pollens of Humulus, Artemisia, and Ambrosia were present from August to September. These results are in agreement with those of similar studies conducted at other locations (Min and Kang 1984, Chang et al. 1988, Park et al. 1993, Oh 1998, Kim et al. 2000, Oh et al. 2000, 2006), which also reported two peak pollen seasons. Furthermore, the types of monthly airborne pollen discovered in our study were similar to those found in other studies. Pollens from Alnus (end of February to March), Cupressaceae (April), Quercus (April to the beginning of May), and Pinus (end of April to May) were detected as dominant in spring. The concentration of pollen in the atmosphere was especially high in May. The peak concentration of each pollen type included in this study appeared 7-10 days earlier in the southern region of Korea than in the middle region. The dominant types of pollen in autumn - Humulus, Artemisia, and Ambrosia - were detected mostly in August and September in all areas. In this study and in a previous study conducted in Busan (Kim et al. 2000), Humulus pollen showed the highest concentration. On the other hand, Artemisia pollen showed the highest concentration in Seoul and the Gyeonggi region. It is difficult to directly compare the concentration of each pollen type identified in this study with concentrations in other regions due to differences in the sampler used, exposure time of glass slides, and preparation methods. For instance, Park et al. (1993), Oh (1998), Kim et al. (2000), and Oh et al. (2000) used volumetric samplers (Rotorod Sampler; Sampling Technologies, Inc., Minnetonka, MN, USA), while Min and Kang (1984) exposed slide glass over 2-3 days, and Chang et al. (1988), who used a Durham sampler placed 
in a garden, reported HP concentration 5-10 times higher than found in this study. Comparison of results from this study with those reported by Chang et al. is limited by differences in the distance between the samplers and surrounding plants in both studies.

We also determined the allergic sensitization rates of the pollen types detected. Parent plants were identified on the basis of the local vegetation, and the flowering season was determined on the basis of the detected pollen. More than $95 \%$ of the annual pollen consisted of TP (mostly Pinus, Quercus and Alnus pollen). Sensitization rates to Pinus and Quercus pollen are minor, whereas that of Alnus pollen is moderate in Europe and America (Falagiani 1990, Subiza et al. 1995). Kim et al. (2000) reported Alnus pollen as a significant allergen associated with spring pollinosis. The concentration of Alnus pollen grains at St. C was five times more than that at Sts. A and $B$ (Table 1). A vegetation survey revealed the parent plant to be mostly Alnus firma, which was planted for erosion control. Therefore, it may be necessary to manage the number of A. firma plants to decrease the concentration of Alnus pollen. The parent plant of Taxodiaceae pollen was identified as Metasequoia glyptostroboides at all three stations. This species had been planted as street trees or garden plants. Furthermore, 10 Cryptomeria japonica plants at St. A also accounted for Taxodiaceae pollen in this region. However, on the basis of the predominant population and the distance between the sampler and the parent plant, we believe Metasequoia to be the more likely parent plant of this pollen type at all three stations. Members of the Cupressaceae family (Thuja, Chamaecyparis and Juniperus) have been regarded as important factors associated with pollinosis in Japan (Kishikawa et al. 2001).

During the peak period of HP from August to November, 95\% of HP consisted of Humulus, Compositae (Artemisia, Ambrosia, etc.), and Gramineae pollen. Parent plants of these pollen grains are mainly distributed along roadsides, at ruderal sites, on riverbanks, at watersides, and on river terraces (Lee 1996, Moon 2005). St. B, which had riversides and river terraces, also had the highest concentration of HP. Sensitization rates in Europe and America are highest for Gramineae pollen, followed by Ambrosia (high), and Artemisia (low) pollen (Falagiani 1990, Subiza et al. 1995, D'Amato et al. 2007). Furthermore, pollinosis prevalence rates associated with these pollen types reached $10 \%$ in Japan (Osaka Prefecture 2007). Although no cases of pollinosis caused by Humulus pollen have been reported in Europe and America, Humulus japonica has been reported as a source of allergenic pollen in Korea and Japan (Hong et al. 1986, Park et al. 1998, Oh et al.
2006, Ministry of the Environment of Japan 2009). Sensitization rates to Humulus pollen have increased in the southern Gyeonggi region of Korea over the past 10 years. Sensitivity to Humulus pollen is most commonly noted in children under the age of 10 years and adults over the age of 40 (Lee 2010). St. B had the highest levels of Humulus pollen, implying that an individual living at or near St. B is exposed to high concentrations of Humulus pollen grains which would lead to a higher prevalence of autumn pollinosis at St. B than at Sts. A and C. Health data are needed to support this assumption. Although Gramineae pollen was detected at lower concentrations than Humulus and Artemisia pollen, it was detected for longer periods (May to November). The sources of Gramineae pollen in the spring may be naturalized plants such as Dactylis glomerata, Avena fatua, and Poa compressa, whereas the sources in autumn may be indigenous plants such as Phragmites communis Trin. and Miscanthus sacchariflorus. In Korea, parent plants of Ambrosia pollen are A. artemisiaefolia, A. trifida, and A. trifida for. integrifolia (Lee 1996). A. artemisiaefolia was observed in vacant lots and abandoned fields at all three stations. A. trifida was detected only at St. B, while A. trifida for. integrifolia was not detected at any station. The types and concentrations of airborne pollen were affected by the surrounding vegetation and environment. Therefore, local data should be continuously collected using the pollen calendar to obtain more accurate information and to prevent pollinosis.

\section{ACKNOWLEDGMENTS}

This study was supported by the Environmental Health Center of Ulsan University Hospital sponsored by national funds from the Ministry of Environment, Korea.

\section{LITERATURE CITED}

Agashe SN, Caulton E. 2009. Pollen and Spores: Application with Special Emphasis on Aerobiology and Allergy. Science Publishers, Enfield, NH, pp 211-216.

Chang NK, Kim NI, Kim JG. 1988. Variation of deposition time and amount of airborne pollens in Mt. Kwan-ak. Korean J Ecol 11: 123-130.

D’Amato G, Cecchi L, Bonini S, Nunes C, Annesi-Maesano I, Behrendt H, Liccardi G, Popov T, van Cauwenberge P. 2007. Allergenic pollen and pollen allergy in Europe. Allergy 62: 976-990.

D’Amato G, Spieksma FThM, Liccardi G, Jäger S, Russo M, 
Kontou-Fili K, Nikkels H, Wüthrich B, Bonini S. 1998. Pollen-related allergy in Europe. Allergy 53: 567-578.

Falagiani P. 1990. Pollinosis. CRC Press, Boca Raton, FL, pp 20-32.

Hong CS, Hwang Y, Oh SH, Kim HJ, Huh KB, Lee SY. 1986. Survey of the airborne pollens in Seoul, Korea. Yonsei Med J 27: 114-120.

Joo YJ. 1965. Studies on Pollinosis, Report 1. Pollen survey in Seoul. Korean J Otolaryngol 8: 11-22.

Kim MJ, Cheon KW, Kim SW. 2000. Aerobiological study for airborne pollen and mold in Pusan. Pediatr Allergy Respir Dis 10: 119-130.

Kishikawa R, Koto E, Iwanaga T, So N, Kamori C, Shoji S, Nishima S, Ishikawa T. 2001. Long-term study of airborne allergic pollen count, C. Japonica and cupressaceae in Japan. Arerugi 50: 369-378. (in Japanese)

Knox RB. 1979. Pollen and Allergy. Edward Arnold, London, pp 49-57.

Korea Meteorological Administration. 2010. Weather Resources Database. http://www.kma.go.kr. Accessed 27 May 2011.

Lee JW. 2010. Changes of the sensitization rates to pollen allergens in the southern Gyeonggi region over the last 10 years. MS Thesis. Ajou University, Suwon, Korea.

Lee WT. 1996. Coloured Standard Illustrations of Korean Plants. Academy Co., Seoul.

Min KU, Kang SY. 1984. Aerobiological and allergological study for airborne pollen in Seoul. Allergy 4: 1-20.

Ministry of the Environment of Japan. 2009. The Manual of Pollinosis and Health Environment, 2009. Ministry of the Environment, Tokyo. (in Japanese)

Moon KH. 2005. Syntaxonomy and synecology of the actual vegetation of Ulsan Metropolitan City. PhD Dissertation. Keimyung University, Daegu, Korea.

Nilsson S. 1973. Scandinavian Aerobiology. No. 18. Swedish Natural Science Research Council Bulletin, Stockholm.
Ogden EC, Raynor GS, Hayes JV, Lewis DM, Haines JH. 1974. Manual for Sampling Airborne Pollen. Hafner Press, New York, pp 49-51.

Oh JW. 1998. Characteristics and distribution of airborne pollen and mold. Pediatr Allergy Respir Dis 8: 1-15.

Oh JW, Kang IJ, Kim SW, Kook MH, Kim BS, Shin KS, Hahn YS, Lee HB, Shon MH, Cheong JT, Lee HR, Kim KE. 2006. The correlation between increased sensitization rate to weeds in children and the annual increase in weed pollen in Korea. Pediatr Allergy Respir Dis 16: 114-121.

Oh JW, Lee HR, Kim JS, Lee KI, Kang YJ, Kim SW, Kook MH, Kang HY, Kim JS, Lee MH, Lee HB, Kim KE, Pyun BY, Lee SI, Han MJ. 2000. Aerobiological study of pollen and mold in the 10 states of Korea. Pediatr Allergy Respir Dis 10: 22-33.

Ong EK, Singh MB, Knox RB. 1995. Seasonal distribution of pollen in the atmosphere of Melbourne: an airborne pollen calendar. Aerobiologia 11: 51-55.

Osaka Prefecture. 2007. Summary of airborne pollen count in Osaka prefecture in Japan, 2007. http://www.pref. osaka.jp/attach/3712/00027395/2007.pdf. Accessed 28 May 2011.

Park CW, Sim SS, Jung M, Park CH, Ryu HS, Lee YM, Cheon SB, Kang SG, Kim JW. 1993. Survey of airborne pollens in Mokpo, 1992. Allergy 13: 342-350.

Park HS, Coi SY, Nahm DH, Kim HY. 1998. Revival of Hop Japanese pollinosis in asthmatic subjects in Kyungki area. J Asthma Allergy Clin Immunol 18: 52-60.

Sahashi N, Kishikawa R, Nishima S, Nagano H. 1993. Standardization of procedures for atmospheric pollen counts and pollen forecast in Japan. Jpn J Palynol 39: 129-134. (in Japanese with English abstract)

Subiza J, Jerez M, Jiménez JA, Narganes MJ, Cabrera M, Varela S, Subiza E. 1995. Allergenic pollen pollinosis in Madrid. J Allergy Clin Immunol 96: 15-23. 